\begin{tabular}{|l|l|l|}
\hline \multicolumn{2}{|c|}{ PublisherInfo } \\
\hline \hline PublisherName & $:$ & BioMed Central \\
\hline \hline PublisherLocation & $:$ & London \\
\hline \hline PublisherImprintName & $:$ & BioMed Central \\
\hline \hline
\end{tabular}

\title{
Diagnosing cancer with artificial neural networks
}

\begin{tabular}{|l|l|l||}
\hline \multicolumn{2}{|c|}{ ArticleInfo } \\
\hline \hline ArticleID & $:$ & 4403 \\
\hline \hline ArticleDOI & $:$ & 10.1186 /gb-spotlight-20020218-01 \\
\hline \hline ArticleCitationID & $:$ & spotlight-20020218-01 \\
\hline \hline ArticleSequenceNumber & $:$ & 69 \\
\hline \hline ArticleCategory & $:$ & Research news \\
\hline ArticleFirstPage & $:$ & 1 \\
\hline \hline ArticleLastPage & $:$ & 2 \\
\hline \hline & & RegistrationDate : 2002-2-18 \\
\hline ArticleHistory & $:$ & OnlineDate \\
\hline \hline ArticleCopyright & $:$ & BioMed Central Ltd2002-18 \\
\hline \hline ArticleGrants & $:$ & \\
\hline \hline ArticleContext & $:$ & 130593311 \\
\hline \hline
\end{tabular}




\section{Tudor Toma}

Email: t.toma@ic.ac.uk

Artificial neural networks (ANNs) are a novel means for analyzing information, and are composed of a large number of highly interconnected processing elements, which can learn through example. In February 13 online Gastroenterology, Florin Selaru and colleagues from University of Maryland School of Medicine, Baltimore, USA, show that ANNs can be used to distinguish different subtypes of neoplastic colorectal lesions in human samples.

Selaru et al. hybridized cDNA microarrays - each containing 8064 cDNA clones - to RNAs derived from 39 colorectal neoplastic specimens with either inflammatory bowel disease-dysplasias (IBDNs) or cancer or sporadic colorectal adenomas (SACs) and cancers. On this model they found that an ANN constructed and trained to differentiate IBDNs from SACs correctly diagnosed 12 of 12-blinded samples in a test set. But hierarchical clustering based on all 8064 clones failed to correctly categorize the samples. In addition, they showed that even with a reduced clone set from 8064 to 97 , ANN retained its capacity for correct diagnosis (Gastroenterology 2002, 122:606-613).

These results show that "ANNs have the potential to discriminate among subtly different clinical entities, such as IBDNs and SACs, as well as to identify gene subsets having the power to make these diagnostic distinctions" concluded the authors.

\section{References}

1. Selaru FM, Xu Y, Yin J, Zou T, Liu TC, Mori Y, Abraham JM, Sato F, Wang S, Twigg C, et al.: Artificial neural networks distinguish among subtypes of neoplastic colorectal lesions. Gastroenterology 2002, 122:606-613., [http://www.gastrojournal.org/cgi/content/abstract/122/3/606]

2. University of Maryland School of Medicine, [http://medschool.umaryland.edu/] 